\title{
PENGARUH PEMBERIAN PUPUK UREA DAN PUPUK ORGANIK CAIR SAMPAH KOTA TERHADAP PERTUMBUHAN DAN PRODUKSI TANAMAN SELADA (Lactuca sativa L.)
}

\author{
Cik Zulia ${ }^{1}$, Deddy Wahyudin Purba ${ }^{1}$, Harmi Dedi Hirawan ${ }^{2}$ \\ ${ }^{1}$ Staff Pengajar Jurusan Agroteknologi, Universitas Asahan \\ ${ }^{2}$ Mahasiswa Jurusan Agroteknologi, Universitas Asahan
}

\begin{abstract}
The research plan was conducted at the Experimental Garden of the University of Asahan Faculty of Agriculture, with flat topography and high place $\pm 15 \mathrm{~m}$ asl. The research plan is carried out from February to April 2017. The materials used in this research are General varieties of lettuce seeds, urea fertilizer, liquid organic fertilizer of urban trash, water, envelopes, label paper, coconut bark as roof shade nursery, insecticide materials Active Deltamethrin $25 \mathrm{~g} / \mathrm{I}$ (Decis $2.5 \mathrm{EC} 0.25-0.5 \mathrm{ml} / \mathrm{I}$ ), Mankozed $80 \mathrm{WP}$ (Dithane M-45) active material fungicide, scales and other materials supporting the conduct of this study, The tool used in this research is hoe, gembor, meter, handsprayer, calculator, scales, planimeter, wire as bamboo bamboo binder and other supporting tools in the implementation of this research. This research was arranged based on Factorial Randomized Block Design (RAK) with 2 treatment factors and 3 replications. The first factor was Urea fertilizer with 4 levels: $U_{0}=0 \mathrm{~g} / \mathrm{plot}, U_{1}=5 \mathrm{~g} / \mathrm{plot}$ and $U_{2}=10 \mathrm{~g} / \mathrm{plot}$ and $U_{3}=15$ $\mathrm{g} /$ plot. The second factor is the provision of liquid organic fertilizer of municipal solid waste consisting of 3 levels ie $\mathrm{K}_{0}=0 \mathrm{ml} / \mathrm{plot}, \mathrm{K}_{1}=0,15 \mathrm{ml} / \mathrm{plot}$ and $\mathrm{K}_{2}=0,30 \mathrm{ml} / \mathrm{plot}$. The results showed that urea fertilizer gave significant effect on the parameters of plant height, number of leaves, production per plant and production per plot, with best dose of U3 treatment (15 $\mathrm{g} / \mathrm{plot}$ ). Provision of liquid organic fertilizers of urban solid waste showed a significant effect on the parameters of plant height, number of leaves, production per production plant per plot, with the best dose on $\mathrm{K} 2$ treatment $(0.30 \mathrm{ml} / \mathrm{plot})$. The interaction between treatment of urea fertilizer and liquid organic fertilizer of urban solid waste did not show any significant effect on growth and production of lettuce

Keywords: Urea Fertilizer, Organic Fertilizer, Municipal Wastewater, Growth, Lettuce
\end{abstract}

\begin{abstract}
ABSTRAK
Penelitian rencana dilaksanakan di Kebun Percobaan Fakultas Pertanian Universitas Asahan, dengan topografi datar dan tinggi tempat $\pm 15 \mathrm{~m}$ dpl. Penelitian rencana dilaksanakan pada bulan Februari sampai bulan April 2017. Bahan-bahan yang digunakan dalam penelitian ini adalah bibit selada varietas General, pupuk urea, pupuk organik cair sampah kota, air, amplop, kertas label, pelepah kelapa sebagai atap naungan persemaian, insektisida bahan aktif Deltametrin $25 \mathrm{~g} / \mathrm{l}$ (Decis 2.5 EC 0,25-0,5 ml/l), fungisida bahan aktif Mankozed 80 WP (Dithane M-45), timbangan dan bahan-bahan lain yang mendukung pelaksanaan penelitian ini, sedangkan alat-alat yang digunakan dalam penelitian ini adalah cangkul, gembor, meteran, handsprayer, kalkulator, timbangan, planimeter, kawat sebagai pengikat bambu persemaian dan alat-alat lain yang mendukung dalam pelaksanaan penelitian ini. Penelitian ini disusun berdasarkan Rancangan Acak Kelompok (RAK) Faktorial dengan 2 faktor perlakuan dan 3 ulangan. Faktor pertama adalah pemberian pupuk Urea dengan 4 taraf yaitu : $U_{0}=0 \mathrm{~g} / \mathrm{plot}, U_{1}=5 \mathrm{~g} /$ plot dan $U_{2}=10 \mathrm{~g} / \mathrm{plot}$ dan $U_{3}=$ $15 \mathrm{~g} /$ plot. Faktor kedua adalah pemberian pupuk organik cair sampah kota terdiri dari 3 taraf yaitu $\mathrm{K}_{0}=0 \mathrm{ml} /$ plot, $\mathrm{K}_{1}=0,15 \mathrm{ml} /$ plot dan $\mathrm{K}_{2}=0,30 \mathrm{ml} /$ plot. Hasil penelitian menunjukkan bahwa pemberian pupuk urea berpengaruh nyata terhadap parameter tinggi
\end{abstract}


tanaman, jumlah daun, produksi per tanaman dan produksi per plot, dengan dosis terbaik pada perlakuan $U_{3}(15 \mathrm{~g} / \mathrm{plot})$. Pemberian pupuk organik cair sampah kota menunjukkan pengaruh nyata terhadap paramter tinggi tanaman, jumlah daun, produksi per tanaman produksi per plot, dengan dosis terbaik pada perlakuan $\mathrm{K}_{2}(0,30 \mathrm{ml} / \mathrm{plot})$. Interaksi kedua perlakuan antara pemberian pupuk urea dan pupuk organik cair sampah kota tidak menunjukkan adanya pengaruh nyata terhadap pertumbuhan dan produksi tanaman selada.

.Kata Kunci: Pupuk Urea, Pupuk Organik Cair Sampah Kota, Selada (Lactuca sativa L)

\section{PENDAHULUAN}

Kebutuhan manusia akan sayuran dari hari ke hari semakin meningkat, yang disebabkan karena bertambahnya jumlah penduduk. Sayuran merupakan tanaman hortikultura yang sangat memegang peranan penting dalam kehidupan manusia. Melonjaknya permintaan akan sayuran segar di pasar-pasar merupakan peningkatan kesadaran konsumen akan gizi. Hal ini disebabkan karena sayuran daun merupakan salah satu sumber vitamin dan mineral essensial yang sangat dibutuhkan oleh tubuh manusia, selain itu sayuran syuran daun banyak mengandung serat (Rukmana, 2006).

Menurut data yang tertera dalam daftar komposisi makanan yang diterbitkan oleh Direktorat Gizi Departemen Kesehatan, komposisi zat-zat makanan yang terkandung dalam setiap $100 \mathrm{~g}$ berat segar selada mengandung 1,2 g protein; 0,2 g lemak; $15 \mathrm{kal}$ kalori; 2,9 g karbohidrat; $22 \mathrm{mg} \mathrm{Ca} ; 25 \mathrm{mg} \mathrm{P} ; 0,5 \mathrm{Fe} ; 540 \mathrm{~g}$ vitamin A; 0,04 mg vitamin B; 8 mg vitamin C; serta 94,8 g air (Haryanto, dkk., 2006).

Tanaman selada (Lactuca sativa) merupakan tanaman yang biasa ditanam di daerah dingin maupun tropis. Tanaman selada merupakan tanaman semusim yang banyak mengandung air. Tanaman ini dimanfaatkan sebagai lalapan oleh masyarakat Indonesia, karena rasanya enak dan lembut (Rukmana, 2006). Selada dapat tumbuh baik di dataran tinggi maupun dataran rendah. Selada juga dapat tumbuh baik pada berbagai jenis tanah, baik lempung berpasir, lempung berdebu, namun yang paling baik (ideal) adalah lempung berpasir yang diberi pupuk organik (Sugeng, 2003).

Ditinjau dari aspek klimatologis, aspek teknis, ekonomis dan bisnis, selada layak diusahakan untuk memenuhi permintaan konsumen yang cukup tinggi dan peluang pasar internasional yang cukup besar (Rukmana, 2006).

Salah satu usaha untuk menaikkan produksi adalah dengan pemeliharaan dan pemupukan yang tepat (Agromedia, 2007). Peningkatan produksi selada dapat dilakukan dengan pemupukan. Pemupukan melalui tanah dapat dilakukan dengan pupuk buatan dan pupuk alami.

Pemupukan bertujuan untuk menambah unsur hara yang dibutuhkan oleh tanaman sebab unsur hara yang terdapat di dalam tanah tidak selalu mencukupi untuk memacu pertumbuhan tanaman secara optimal (Salikin, 2003). Selama ini petani cenderung menggunakan pupuk anorganik secara terus menerus. Pemakaian pupuk anorganik yang relatif tinggi dan terus-menerus dapat menyebabkan dampak negatif terhadap lingkungan tanah, sehingga menurunkan produktivitas lahan pertanian. Kondisi tersebut menimbulkan pemikiran untuk kembali menggunakan bahan organik sebagai sumber pupuk organik. Penggunaan pupuk organik mampu menjaga keseimbangan lahan dan meningkatkan produktivitas lahan serta mengurangi dampak lingkungan tanah.

Hara nitrogen $(\mathrm{N})$ merupakan hara makro yang sangat dibutuhkan oleh tanaman, hara $\mathrm{N}$ dapat diperoleh dari hara $\mathrm{N}$ seperti urea $\left.\left[\mathrm{CO}\left(\mathrm{NH}_{2}\right)_{2}\right], \mathrm{ZA}\left[\mathrm{NH}_{4}\right)_{2} \mathrm{SO}_{4}\right]$, ammonium 
cloride $\left(\mathrm{NH}_{4} \mathrm{Cl}\right)$, natrium nitrat $\left(\mathrm{NaNO}_{3}\right)$, dan pupuk majemuk NPK. Pupuk urea merupakan pupuk tunggal yang hanya mengandung satu unsur hara primer yaitu $42 \%-46 \% \mathrm{~N}$. Proporsi dan waktu pemberian $\mathrm{N}$ berinteraksi terhadap pertumbuhan dan produksi tanaman seperti panjang tanaman, diameter batang, banyak buah dan produksi. (Sebayang, 2004).

Penggunaan pupuk organik mampu menjadi solusi dalam mengurangi pemakaian pupuk anorganik yang berlebihan. Namun kelemahan pupuk organik pada umumnya adalah kandungan unsur hara yang rendah dan lambat tersedia bagi tanaman. Pupuk organik dapat berbentuk padat maupun cair. Kelebihan pupuk organik cair adalah unsur hara yang dikandungnya lebih cepat tersedia dan mudah diserap akar tanaman. Salah satu pupuk organik dalam bentuk cair adalah pupuk organik cair dari limbah sayuran.

Dengan berkembangnya model pertanian zero waste, tidak akan membiarkan hasil ikutan menjadi limbah atau tidak bermanfaat (Sunanto dan Nasrullah, 2012). Oleh karena itu, maka peningkatan produksi limbah sebenarnya tidak terlampau bermasalah lagi karena dapat diproses menjadi pupuk organik padat dan pupuk organik cair seperti hasil fermentasi limbah sayuran. Untuk meningkatkan kualitas hasil pembuatan pupuk organik padat maupun pupuk organik cair dapat ditambahkan molase dan mikroorganisme seperti EM4.

Hasil analisis laboratorium terhadap limbah sayuran diperoleh bahwa pada awal penelitian mengandung kadar air 88,78\%; pH 7,68.. Pada hari ke 25 setelah fermentasi dengan penambahan EM4 $350 \mathrm{~mL}$ dihasilkan pupuk organik cair dengan kandungan unsur hara tertinggi yaitu $1 \% \mathrm{~N} ; 1,98 \% \mathrm{P} ; 0,85 \% \mathrm{~K}$; dan rasio $\mathrm{C} / \mathrm{N} 30$, total solid $34,78 \%$; Chemical Demand Oxygen (COD) 2386 mg.L-1; biogas 13 mL; dan pH 5,55 (Siboro et al., 2013).

\section{METODE PENELITIAN}

Penelitian dilaksanakan di Kebun Percobaan Fakultas Pertanian Universitas Asahan, dengan topografi datar dan tinggi tempat $\pm 15 \mathrm{~m}$ dpl. Tipe iklim Oldeman termasuk tipe iklim E1 dan jenis tanah Alluvial. Curah hujan antara $1.917 \mathrm{~mm}-3.884 \mathrm{~mm}$, dengan ratarata curah hujan tahunan $2.900 \mathrm{~mm}$. Suhu berkisar $20,4-32,7^{\circ} \mathrm{C}$ dan kelembaban udara antara 82\% - 94\%. Penelitian dilaksanakan pada bulan Februari sampai bulan April 2017.

Bahan-bahan yang digunakan dalam penelitian ini adalah bibit selada varietas General, pupuk urea, pupuk organik cair sampah kota, air, amplop, kertas label, pelepah kelapa sebagai atap naungan persemaian, insektisida bahan aktif Deltametrin $25 \mathrm{~g} / \mathrm{l}$ (Decis 2.5 EC 0,25 - 0,5 ml/l), fungisida bahan aktif Mankozed 80 WP (Dithane M-45), timbangan dan bahan-bahan lain yang mendukung pelaksanaan penelitian ini

Alat-alat yang digunakan dalam penelitian ini adalah cangkul, gembor, meteran, handsprayer, kalkulator, timbangan, planimeter, kawat sebagai pengikat bambu persemaian dan alat-alat lain yang mendukung dalam pelaksanaan penelitian ini

Penelitian dilakukan dengan menggunakan Rancangan Acak Kelompok (RAK) Faktorial yang terdiri dari 2 taraf dengan 3 level perlakuan untuk faktor pertama dan 4 level perlakuan untuk faktor kedua, yaitu

Faktor pertama adalah pemberian pupuk urea $(U)$ yang terdiri dari 4 (empat) taraf yaitu

$$
\begin{aligned}
& \cup_{0}=0 \mathrm{~g} / \mathrm{plot} \\
& \cup_{1}=5 \mathrm{~g} / \mathrm{plot} \\
& \cup_{2}=10 \mathrm{~g} / \mathrm{plot} \\
& \cup_{3}=15 \mathrm{~g} / \mathrm{plot}
\end{aligned}
$$


Sedangkan faktor kedua adalah pemberian pupuk organik cair sampah kota (K) terdiri dari 3 (empat) taraf yaitu :

$$
\begin{aligned}
& \mathrm{K}_{0}=\text { kontrol } \\
& \mathrm{K}_{1}=0,15 \mathrm{ml} / \mathrm{plot} \\
& \mathrm{K}_{2}=0,30 \mathrm{ml} / \mathrm{plot}
\end{aligned}
$$

Parameter tanaman yang diamati dalam penelitian adalah tinggi tanaman $(\mathrm{cm})$, jumlah daun (helai), produksi per tanaman $(\mathrm{g})$ dan produksi per plot $(\mathrm{kg})$.

\section{Tinggi Tanaman $(\mathbf{c m})$}

\section{HASIL DAN PEMBAHASAN}

Hasil uji beda rataan pengaruh pemberian pupuk urea dan pupuk organik cair sampah kota terhadap tinggi tanaman selada dapat dilihat pada Tabel 1 berikut ini.

Tabel 1. Hasil Uji Beda Rataan Pengaruh Pemberian Pupuk Urea dan Pupuk Organik Cair Sampah Kota Terhadap Tinggi Tanaman Selada $(\mathrm{cm})$ umur 28 HST.

\begin{tabular}{ccccc}
\hline Perlakuan & $\mathrm{K}_{0}$ & $\mathrm{~K}_{1}$ & $\mathrm{~K}_{2}$ & Rataan \\
\hline $\mathrm{U}_{0}$ & 13,17 & 14,02 & 14,37 & $13,85 \mathrm{~d}$ \\
$\mathrm{U}_{1}$ & 14,58 & 15,08 & 15,45 & $15,04 \mathrm{c}$ \\
$\mathrm{U}_{2}$ & 15,13 & 16,23 & 16,67 & $16,01 \mathrm{~b}$ \\
$\mathrm{U}_{3}$ & 16,72 & 17,23 & 17,30 & $17,08 \mathrm{a}$ \\
\hline Rataan & $14,90 \mathrm{~b}$ & $15,64 \mathrm{ab}$ & $15,95 \mathrm{a}$ & $\mathrm{KK}=2,55 \%$
\end{tabular}

Ket: Angka-angka yang diikuti oleh huruf yang sama pada baris atau kolom yang sama menunjukkan tidak berbeda nyata pada taraf $5 \%$ dengan menggunakan Uji BNJ.

Dari Tabel 1 dilihat bahwa pemberian pupuk urea dengan dosis $15 \mathrm{~g} / \mathrm{plot}\left(\mathrm{U}_{3}\right)$ memiliki tinggi tanaman tertinggi yaitu $17,08 \mathrm{~cm}$, berbeda nyata dengan perlakuan $10 \mathrm{~g} / \mathrm{plot}$ $\left(U_{2}\right) 16,01 \mathrm{~cm}, 5 \mathrm{~g} /$ plot $\left(U_{1}\right) 15,04 \mathrm{~cm}$ dan $0 \mathrm{~g} /$ plot $\left(U_{0}\right) 13,85 \mathrm{~cm}$, sedangkan perlakuan $U_{2}$, $\mathrm{U}_{1}$ dan $\mathrm{U}_{0}$ menunjukkan saling berbeda nyata. Perlakuan pemberian pupuk organik cair sampah kota dengan perlakuan $0,30 \mathrm{ml} /$ plot $\left(\mathrm{K}_{2}\right)$ memiliki tinggi tanaman tertinggi yaitu $15,95 \mathrm{~cm}$, tidak berbeda nyata dengan perlakuan $0,15 \mathrm{ml} /$ plot $\left(\mathrm{K}_{1}\right) 15,64 \mathrm{~cm}$, tetapi berbeda nyata dengan perlakuan $0 \mathrm{ml} /$ plot $\left(\mathrm{K}_{0}\right) 14,90 \mathrm{~cm}$, sedangkan perlakuan $\mathrm{K}_{1}$ dan $\mathrm{K}_{0}$ menunjukkan berbeda nyata.

\section{Jumlah daun (helai)}

Hasil uji beda rataan pengaruh pemberian pupuk urea dan pupuk organik cair sampah kota terhadap jumlah daun tanaman selada dapat dilihat pada Tabel 2 berikut ini. 
Tabel 2. Hasil Uji Beda Rataan Pengaruh Pemberian Pupuk Urea dan Pupuk Organik Cair Sampah Kota Terhadap Jumlah Daun Tanaman Selada (helai) umur 28 HST.

\begin{tabular}{ccccc}
\hline Perlakuan & $\mathrm{K}_{0}$ & $\mathrm{~K}_{1}$ & $\mathrm{~K}_{2}$ & Rataan \\
\hline $\mathrm{U}_{0}$ & 19,92 & 20,00 & 21,42 & $20,44 \mathrm{~b}$ \\
$\mathrm{U}_{1}$ & 20,00 & 21,00 & 20,50 & $20,50 \mathrm{~b}$ \\
$\mathrm{U}_{2}$ & 21,08 & 21,33 & 21,75 & $21,39 \mathrm{a}$ \\
$\mathrm{U}_{3}$ & 21,08 & 20,67 & 22,42 & $21,39 \mathrm{a}$ \\
\hline Rataan & $20,52 \mathrm{~b}$ & $20,75 \mathrm{~b}$ & $21,52 \mathrm{a}$ & $\mathrm{KK}=4,34 \%$ \\
\hline
\end{tabular}

Ket: Angka-angka yang diikuti oleh huruf yang sama pada baris atau kolom yang sama menunjukkan tidak berbeda nyata pada taraf $5 \%$, dengan Uji BNJ.

Dari Tabel 2 dilihat bahwa pemberian pupuk urea dengan dosis $15 \mathrm{~g} /$ plot $\left(\mathrm{U}_{3}\right)$ memiliki jumlah daun tanaman terbanyak yaitu 21,39 helai, tidak berbeda nyata dengan perlakuan $10 \mathrm{~g} /$ plot $\left(U_{2}\right) 21,39$ helai, $5 \mathrm{~g} /$ plot $\left(U_{1}\right) 20,50$ helai dan $0 \mathrm{~g} /$ plot $\left(U_{0}\right) 20,44$ helai, sedangkan perlakuan $U_{1}$ dan $U_{0}$ menunjukkan tidal saling berbeda nyata. Perlakuan pemberian pupuk organik cair sampah kota dengan perlakuan $0,30 \mathrm{ml} / \mathrm{plot}\left(\mathrm{K}_{2}\right)$ memiliki jumlah daun tanaman terbanyak yaitu 21,52 helai, berbeda nyata dengan perlakuan 0,15 $\mathrm{ml} /$ plot $\left(\mathrm{K}_{1}\right)$ 20,75 helai, dan perlakuan $0 \mathrm{ml} /$ plot $\left(\mathrm{K}_{0}\right)$ 20,52 helai, sedangkan perlakuan $\mathrm{K}_{1}$ dan $\mathrm{K}_{0}$ menunjukkan tidak berbeda nyata

\section{Produksi per tanaman (g).}

Hasil uji beda rataan pengaruh pemberian pupuk urea dan pupuk organik cair sampah kota terhadap produksi per tanaman selada dapat dilihat pada Tabel 3 berikut ini.

Tabel 3. Hasil Uji Beda Rataan Pengaruh Pemberian Pupuk Urea dan Pupuk Organik Cair Sampah Kota Terhadap Produksi per Tanaman Selada (g)

\begin{tabular}{ccccc}
\hline Perlakuan & $\mathrm{K}_{0}$ & $\mathrm{~K}_{1}$ & $\mathrm{~K}_{2}$ & Rataan \\
\hline $\mathrm{U}_{0}$ & 65,00 & 73,33 & 88,33 & $75,56 \mathrm{~d}$ \\
$\mathrm{U}_{1}$ & 83,33 & 101,67 & 96,67 & $93,89 \mathrm{c}$ \\
$\mathrm{U}_{2}$ & 100,00 & 110,00 & 100,00 & $103,33 \mathrm{~b}$ \\
\hline $\mathrm{U}_{3}$ & 106,67 & 116,67 & 125,00 & $116,11 \mathrm{a}$ \\
\hline Rataan & $88,75 \mathrm{~b}$ & $100,42 \mathrm{a}$ & $102,50 \mathrm{a}$ & $\mathrm{KK}=12,84 \%$ \\
\hline
\end{tabular}

Ket: Angka-angka yang diikuti oleh huruf yang sama pada baris atau kolom yang sama menunjukkan tidak berbeda nyata pada taraf $5 \%$ dengan menggunakan Uji BNT.

Dari Tabel 3 dilihat bahwa pemberian pupuk urea dengan dosis $15 \mathrm{~g} / \mathrm{plot}\left(\mathrm{U}_{3}\right)$ memiliki produksi per tanaman terbanyak yaitu $116,11 \mathrm{~g}$, berbeda nyata dengan perlakuan $10 \mathrm{~g} / \mathrm{plot}\left(\mathrm{U}_{2}\right)$ 103,33 g, $5 \mathrm{~g} / \mathrm{plot}\left(\mathrm{U}_{1}\right) 93,89 \mathrm{~g}$ dan $0 \mathrm{~g} / \mathrm{plot}\left(\mathrm{U}_{0}\right) 75,56 \mathrm{~g}$, sedangkan perlakuan $U_{1}$ dan $U_{0}$ menunjukkan berbeda nyata. Perlakuan pemberian pupuk organik cair sampah kota dengan perlakuan $0,30 \mathrm{ml} /$ plot $\left(\mathrm{K}_{2}\right)$ memiliki produksi per tanaman terbanyak yaitu $102,50 \mathrm{~g}$, tidak berbeda nyata dengan perlakuan $0,15 \mathrm{ml} / \mathrm{plot}\left(\mathrm{K}_{1}\right) 100,42 \mathrm{~g}$, tetapi berbeda nyata dengan perlakuan $0 \mathrm{ml} /$ plot $\left(\mathrm{K}_{0}\right) 88,75 \mathrm{~g}$, sedangkan perlakuan $\mathrm{K}_{1}$ dan $\mathrm{K}_{0}$ menunjukkan berbeda nyata. 


\section{Produksi per plot $(\mathbf{k g})$}

Hasil uji beda rataan pengaruh pemberian pupuk urea dan pupuk organik cair sampah kota terhadap produksi per plot tanaman selada dapat dilihat pada Tabel 4 berikut ini.

Tabel 4.Hasil Uji Beda Rataan Pengaruh Pemberian Pupuk Urea dan Pupuk Organik Cair Sampah Kota Terhadap Produksi per Plot Tanaman Selada $(\mathrm{kg})$.

\begin{tabular}{ccccc}
\hline Perlakuan & $\mathrm{K}_{0}$ & $\mathrm{~K}_{1}$ & $\mathrm{~K}_{2}$ & Rataan \\
\hline $\mathrm{U}_{0}$ & 0,78 & 0,88 & 1,06 & $0,91 \mathrm{~d}$ \\
$\mathrm{U}_{1}$ & 1,00 & 1,22 & 1,16 & $1,13 \mathrm{c}$ \\
$\mathrm{U}_{2}$ & 1,20 & 1,32 & 1,20 & $1,24 \mathrm{~b}$ \\
$\mathrm{U}_{3}$ & 1,28 & 1,40 & 1,50 & $1,39 \mathrm{a}$ \\
\hline Rataan & $1,07 \mathrm{~b}$ & $1,21 \mathrm{a}$ & $1,23 \mathrm{a}$ & $\mathrm{KK}=12,84 \%$
\end{tabular}

Ket: Angka-angka yang diikuti oleh huruf yang sama pada baris atau kolom yang sama menunjukkan tidak berbeda nyata pada taraf $5 \%$ dengan menggunakan Uji BNT

Dari Tabel 4 dilihat bahwa pemberian pupuk urea dengan dosis $15 \mathrm{~g} /$ plot $\left(\mathrm{U}_{3}\right)$ memiliki produksi per plot terbanyak yaitu $1,39 \mathrm{~kg}$, berbeda nyata dengan perlakuan 10 $\mathrm{g} /$ plot $\left(\mathrm{U}_{2}\right) 1,24 \mathrm{~kg}, 5 \mathrm{~g} / \mathrm{plot}\left(\mathrm{U}_{1}\right) 1,13 \mathrm{~kg}$ dan $0 \mathrm{~g} /$ plot $\left(\mathrm{U}_{0}\right)$ 0,91 kg, sedangkan perlakuan $U_{1}$ dan $\mathrm{U}_{0}$ menunjukkan berbeda nyata. Perlakuan pemberian pupuk organik cair sampah kota dengan perlakuan $0,30 \mathrm{ml} /$ plot $\left(\mathrm{K}_{2}\right)$ memiliki produksi per plot terbanyak yaitu 1,23 kg, tidak berbeda nyata dengan perlakuan $0,15 \mathrm{ml} /$ plot $\left(\mathrm{K}_{1}\right) 1,21 \mathrm{~kg}$, tetapi berbeda nyata dengan perlakuan $0 \mathrm{ml} /$ plot $\left(\mathrm{K}_{0}\right) 1,07 \mathrm{~kg}$, sedangkan perlakuan $\mathrm{K}_{1}$ dan $\mathrm{K}_{0}$ menunjukkan berbeda nyata

\section{KESIMPULAN}

Pemberian pupuk urea menunjukkan berpengaruh nyata terhadap parameter tinggi tanaman, jumlah daun, produksi per tanaman dan produksi per plot, dengan dosis terbaik pada perlakuan $\mathrm{U}_{3}(15 \mathrm{~g} / \mathrm{plot})$

Pemberian pupuk organik cair sampah kota menunjukkan pengaruh nyata terhadap paramter tinggi tanaman, jumlah daun, produksi per tanaman produksi per plot, dengan dosis terbaik pada perlakuan $\mathrm{K}_{2}(0,30 \mathrm{ml} / \mathrm{plot})$

Interaksi kedua perlakuan antara pemberian pupuk urea dan pupuk organik cair sampah kota tidak menunjukkan adanya pengaruh nyata terhadap pertumbuhan dan produksi tanaman selada.

\section{DAFTAR PUSTAKA}

Agustina, L. 2004. Dasar Nutrisi Tanaman. Rineka Cipta. Jakarta Agromedia, 2007. Petunjuk Pemupukan. Penerbit Agromedia Pustaka, Jakarta

Asmar, 2008. Pengaruh Pemberian Kompos Sampah Kota dan Urea, TSP, KCl Pada Regosol Terhadap Serapan Hara N, P, K Tanaman Selada (Lactuca sativa L). Fakultas Pertanian Universitas Andalas. Padang

Haryanto, E., Suhartini,T., dan Rahayu,E. 2006. Sawi dan Selada. Penebar Swadaya. Jakarta 
Hakim, N. M, Y. Nyakpa, AM. Lubis., S. G. Nugroho., M. R. Saul., M. A. Diha., G. B. Hong., dan H. H. Bailey. 2006. Dasar-dasar Ilmu Tanah. Penerbit Universitas Lampung. Lampung. 396 hal

Ma'ruf, A. Sinaga, A. 2016. Pengaruh Pemanasan Global Terhadap Beberapa Tanaman C3 Di Indonesia. Bernas

Ma'ruf, A. Mardu, R. Andayani, N. 2014. Respon Bibit Mucuna bracteata Terhadap Intensitas Sinar Matahari. Institut Pertanian Stiper Yogyakarta

Ma'ruf, A. 2016. Respon Beberapa Kultivar Tanaman Pangan Terhadap Salinitas. Bernas

Ma'ruf, A. Zulia, C. Safruddin. 2017. Legume Cover Crop di Perkebunan Kelapa Sawit. Forum Pertanian Asahan

Rukmana. 2006. Bertanam Selada dan Buncis. Kanisius. Yogyakarta

Mulyati, R.S. Tejowulan dan V.A. Octarina, 2007. Respon Tanaman Tomat terhadap Pemberian Pupuk Kandang Ayam dan Urea terhadap Pertumbuhan dan Serapan N. Agroteksos Volume 17 Nomor 1. Staf Pengajar Jurusan IImu Tanah, Fakultas Pertanian UNRAM

Novizan, 2005. Petunjuk Pemupukan yang Efektif. Agromedia Pustaka, Jakarta.

Notohadiprawiro, T. 2001. Tanah dan Lingkungan. Dirjen Pendidikan Tinggi. Depdikbud. Jakarta. Hal 34.

Rosmarkum, A dan Yuwono, N. W. 2002. Ilmu Kesuburan Tanah. Cetakan Ke-5. Yogyakarta: PT. Kanisius

Salikin, K.A, 2003. Sistem Pertanian Berkelanjutan. Kanisius, Yogyakarta.

Sebayang H.T. 2004. Pengaruh Pengolahan Tanah dan Penempatan Urea Tablet Serta Proporsi dan Waktu Pemberian Pupuk Urea Terhadap Pertumbuhan dan Hasil Tanaman Jagung (Zea mays. L). Balai Penelitian Tanaman Jagung dan Serealia Lain. Maros.

Siboro ES, Surya E, Herlina N. 2013. Pembuatan pupuk cair dan biogas dari campuran limbah sayuran. Jurnal Teknik Kimia USU 2(3): 40-43.

Sinaga, A. Ma'ruf, A. 2016. Tanggapan Hasil Pertumbuhan Tanaman Jagung Akibat Pemberian Pupuk Urea, SP-36, dan KCl. Bernas

Sugeng. 2003. Budidaya Tanaman Sayur-sayuran. Penebar Swadaya. Jakarta

Sunanto dan Nasrullah. 2012. Kajian model pertanian zero waste dengan pendekatan sistem integrasi tanaman jagung-ternak sapi di Sulawesi Selatan. Prosiding InSINas: 223-228.

Wiyanto, G. Ma'ruf, A. Puspaningrum, E, S. Panen Rupiah dari Ladang Jahe. Bhafana Publishing 